IZA DP No. 7244

Distributional Consequences of Capital Accumulation, Globalisation and Financialisation in the US

Marika Karanassou

Hector Sala

February 2013 


\title{
Distributional Consequences of Capital Accumulation, Globalisation and Financialisation in the US
}

\author{
Marika Karanassou \\ Queen Mary, University of London \\ and IZA \\ Hector Sala \\ Universitat Autònoma de Barcelona \\ and IZA
}

Discussion Paper No. 7244

February 2013

IZA

P.O. Box 7240

53072 Bonn

Germany

Phone: +49-228-3894-0
Fax: +49-228-3894-180
E-mail: iza@iza.org

Any opinions expressed here are those of the author(s) and not those of IZA. Research published in this series may include views on policy, but the institute itself takes no institutional policy positions. The IZA research network is committed to the IZA Guiding Principles of Research Integrity.

The Institute for the Study of Labor (IZA) in Bonn is a local and virtual international research center and a place of communication between science, politics and business. IZA is an independent nonprofit organization supported by Deutsche Post Foundation. The center is associated with the University of Bonn and offers a stimulating research environment through its international network, workshops and conferences, data service, project support, research visits and doctoral program. IZA engages in (i) original and internationally competitive research in all fields of labor economics, (ii) development of policy concepts, and (iii) dissemination of research results and concepts to the interested public.

IZA Discussion Papers often represent preliminary work and are circulated to encourage discussion. Citation of such a paper should account for its provisional character. A revised version may be available directly from the author. 


\section{ABSTRACT \\ Distributional Consequences of Capital Accumulation, Globalisation and Financialisation in the US}

In this paper we examine the dynamic contributions of capital accumulation, globalisation, and financialisation to the functional-personal income distribution nexus. We analyse the labour share under the prism of monopoly and frictional growth, and disclose the dramatic upward trend in inequality. On this basis, we estimate a two-equation model for the income distribution in the US over the 1960-2009 period. We show that the labour share is affected positively by capital intensity and negatively by trade, while the Gini statistic is fueled by the falling labour share and increasing financial payments. Using counterfactual simulations, a key finding is that the decrease in capital intensity in the eighties accounted for about $76 \%$ of the labour share fall, while its increase in the 2000s prevented inequality from worsening three times more than it actually did. In turn, had financialisation not increased after 2005, inequality would have decreased to its level in the early noughties. In the Great Recession years of tense socioeconomic conditions, looking at income distribution through the lens of the wage-productivity gap could enlighten economic policy.

JEL Classification: D33, E25

Keywords: income distribution, labour share, wage gap, inequality, capital intensity, financialisation, trade

Corresponding author:

Hector Sala

Department d'Economia Aplicada

Universitat Autònoma de Barcelona

Edifici B

08193 Bellaterra

Spain

E-mail: hector.sala@uab.es

\footnotetext{
* We are grateful to the Spanish Ministry of Science and Innovation for financial support through grant ECO2009-07636.
} 


\section{Introduction}

For the last three decades, the personal and functional distributions of income have followed divergent trends in the US. While increasing inequality in personal income distribution has been pushing the Gini index relentlessly upwards, the evolution in the functional distribution of income has been characterised by a downward trend in the labour income share (Figure 1). ${ }^{1}$ Since the labour income share can also be envisaged as the wageproductivity gap, its downward trend is a mere reflection of wages lagging further behind labour productivity.

The aim of this paper is to identify the driving forces of the wage-productivity gap and inequality, and evaluate their consequences for the functional-personal income distribution nexus.

Figure 1. Labour income share and income inequality in the US.

a. Absolute values.

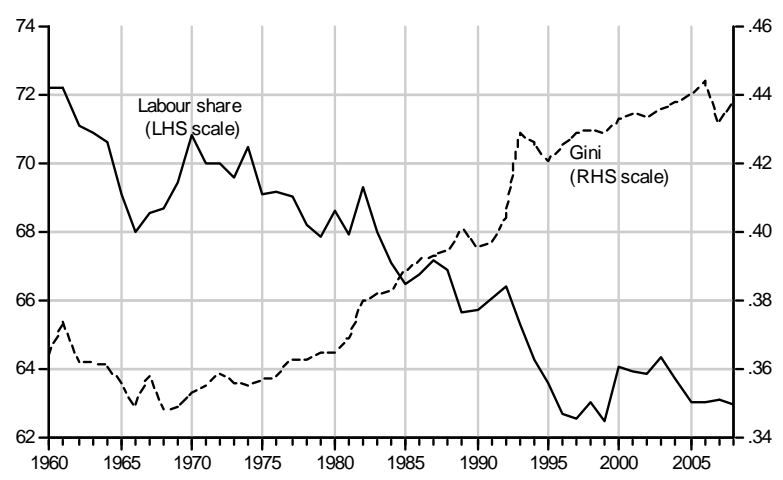

b. Index $100=1960$.

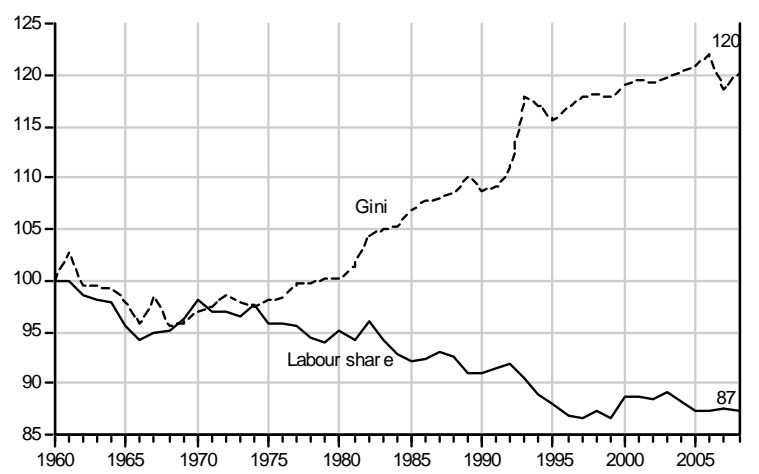

In earlier work we argued that the falling labour share is a long-run structural phenomenon due to the interplay of wage dynamics and productivity growth, i.e. frictional growth. ${ }^{2}$ More emphatically, the wage gap does not vanish even when the classical assumption of a unitary long-run elasticity of wages with respect to productivity holds. In this paper we take a step forward and argue that the interplay between lags and growth can be detected in the theory of economic dynamics in Kalecki ([1954]2009). Understanding the wage-productivity gap as a structural development paves the way for the analysis of its effects on economic activity.

An initial phase of our enquiry showed that the falling labour share is an important channel increasing personal income inequality and supporting employment. This led us to evaluate what we call the inequality-employment sensitivity ratio (Karanassou and

\footnotetext{
${ }^{1}$ The rise in income inequality has been documented by, among others, Atkinson, Piketty and Saez (2011), Saez (2010), Piketty and Saez (2006), and Wolff and Zacharias (2006). For the labour share time path and its determinants see, for example, Milberg and Winkler (2010a), Stockhammer (2009), IMF (2007), and Bentolila and Saint-Paul (2003).

${ }^{2}$ See Karanassou and Sala (2011). The term frictional growth has been coined by M. Karanassou, H. Sala and D.J. Snower in their work since 2005.
} 
Sala, 2012), ${ }^{3}$ which can be seen as a barometer of the two-sided role of the falling labour share in economic activity: wider wage gaps are associated with lower unit labour costs that boost employment and, at the same time, they further lead to the squeeze of the middle class by overloading its socioeconomic burden. In effect, the employment support of the falling labour share, from the 1970s to the late 2000s, "sweetened" its distributional impact and diverted attention away from the issue of increasing inequality.

Since this employment/wage gap finding is consistent with the view that wages drive employment and employment drives output expansion (growth), it is important to clarify our position on this respect. In their thorough analytical exposition, Bhaduri and Marglin (1990) associated the negative relation between real wages and employment with a profitled expansion obtained by profit maximisation or, alternatively, when "aggregate demand is higher owing to the strong response of investment to the higher profit margin/share brought about by a lower real wage rate" (ib., p.379). Projecting on the same argument, the reverse case of a wage-led expansion can be derived: employment (output) contracts at a lower real wage due to the relatively weak response of investment to the higher profit margin/share.

While our work is in accordance with the inverse relation between real wages and employment, prepounded by Keynes in the General Theory and endorsed by the neoclassical school of thought, it refutes the conventional wisdom that the labour income share is neutral to the performance of macro-labour markets. It may be tantalising to place the finding of an inverse relation between the wage-productivity gap and employment along the lines of a profit-led growth model. However, in the light of the financial developments and high personal borrowing of recent decades, the scenarios of wage-led and profit-led growth/demand need to be reassessed.

They need to accommodate the fact that while wages have been lagging further behind productivity, spending has kept up with output by the expansion of consumer debt - the ratio of household debt to GDP jumped from $75 \%$ in 2000 to $104 \%$ in 2007 (BIS, 2009). While we have been witnessing a falling labour share accompanied by rising personal debt, profits have been increasing without being reinvested. For example, Reuters (2010, April 15) reports that "The Fortune 500 largest U.S. companies slashed a record 821,000 jobs last year, even as their collective profit soared more than three-fold to $\$ 391$ billion, according to the business magazine". Martin Wolf in the Financial Times (2008, February 5) notes: "the profits of financial companies jumped from below 5 per cent of total corporate profits, after tax, in 1982 to 41 per cent in 2007, even though their share of corporate value added only rose from 8 per cent to 16 per cent." Our thesis has thus been confined to the analysis

\footnotetext{
${ }^{3}$ The negative relation between the labour share and inequality is also documented by Checchi and García-Peñalosa (2010) in their regression of the Gini statistic. Giovannoni (2010) argues that the highquality datasets by the UTIP-UNIDO and the OECD-SULCI clearly show a strong link between the lower wage share and higher inequality since 1980 .
} 
of the role of the wage gap in the income distribution nexus. It is beyond the scope of this paper to examine whether our presumed profit-led result is due to a strong response of investment to higher profits, or rather to a relatively weak response of investment to higher profits in conjunction with a debt-driven demand.

This work shows that the central determinants of the labour share and the Gini coefficient are capital intensity, trade (or the degree of openness), and financial payments. These variables are regarded as reasonably good proxies of the critical macroeconomic phenomena of capital accumulation, globalisation, and financialisation. The later refers to the engagement of the non-financial sector (global/oligopolistic industries) in financial markets. $^{4}$

Estimating a two-equation system over the 1960-2009 period, we find that (i) the functional income distribution is mainly driven by the capital intensity and trade factors, and (ii) inequality is fueled by the falling labour share and increasing financial payments. Put differently, while there is a direct effect of financialisation on the personal income distribution, capital accumulation and globalisation affect inequality indirectly via the labour share. In addition, it can be argued that capital intensity is the transmission channel of financialisation to the functional income distribution.

On the basis of the statistical significance and adequacy of our model, we measure its economic significance by evaluating the distributional consequences of capital intensity, trade, and financial payments. To this end we carry out counterfactual simulations over selected time spans after 1980 that answer the question: How have the ups and downs of these three variables contributed to the evolution of the labour share and the Gini index? The results are revealing. The positive effect of capital accumulation on the labour share has been a vital force in the distributional developments throughout the decades. On the other hand, financialisation is a key factor to increasing inequality.

Regarding the personal income distribution, had capital accumulation remained at its low value in 2000 for the rest of the noughties (rather than increasing), income inequality would have worsened three times more than it actually did. In contrast, had financialisation stayed as low as its 2005 value during the second half of the decade (instead of accelerating), the Gini coefficient would have fallen back to its level in 2000. Prior to 2000, the slowdown in capital intensity led to significantly more inequality which was reinforced by the increases in financialisation. Furthermore, the higher degree of openness contributed to ease inequality, albeit by less than one percentage point (pp) in each decade.

Regarding the functional income distribution, while the decrease in capital accumulation was the biggest contributor to the widening wage gap during the eighties and the

\footnotetext{
${ }^{4}$ See, for example, Stockhammer (2004), Milberg and Winkler (2010a), and Hatgioannides and Karanassou (2011).
} 
nineties, the higher capital intensity in the 2000s prevented the labour share from falling by an extra $2.8 \mathrm{pp}$. On the other hand, and although the labour share effect of the trade factor was rather small in the previous decades, the labour share would have stabilised at its year 2000 value had trade not increased in the noughties.

Section 2 presents the functional income distribution under the prism of the degree of monopoly and frictional growth. Section 3 discusses the measures of inequality and comments on the steep upward trend of the personal income distribution since the eighties. Section 4 outlines the labour share and Gini coefficient relations of our empirical model, while Section 5 presents the estimation results. Having identified capital accumulation, globalisation, and financialisation as the driving forces of the labour share and inequality, Section 6 evaluates their distributional consequences. Finally, Section 7 concludes.

\section{Functional Income Distribution}

In the context of our work, it is important to stress that the labour income share is in effect the wage share, which through the wage-productivity relationship can be seen as the wage gap:

$$
\text { labour share } \equiv \frac{\text { wages }}{\text { GDP }}=\frac{\text { wages/employees }}{\text { GDP/employees }}=\frac{\text { avg. wage }}{\text { productivity }} \equiv \text { wage gap. }
$$

If, say, a $10 \%$ productivity gain is accompanied by a $10 \%$ growth in the average real wage, then the wage gap is zero (i.e. the labour share is stable). On the other hand, the lower the wage growth, the more wages trail productivity gains and thus the wider is the wage gap (i.e. the lower is the labour share). Milberg and Winkler (2010b) point out that the labour share is a good indicator of economic insecurity as it reflects both labour demand and wage changes. Milberg and Schöller (2009, p.20) note that the labour share has not fallen as much as in other countries "partly due to the fact that the large levels of CEO compensation in the U.S., including stock options, are officially accounted in labor income."

Figure 1 shows that the labour share fell by $13 \%$ from 1960 to 2009 . At the same time, the evidence provided by Foster, McChesney, and Jonna (2011, p.5) suggests that economic concentration increased sharply during the same period. Following Kalecki's study we argue that the widening wage-productivity gap signifies the increasing power of a monopolistic environment over competitive markets. 


\subsection{Falling Labour Shares and the Degree of Monopoly: The Kalecki Argument}

To a large extent, the reality verdict of a falling labour share, globalisation and the ensuing concentration in corporate power since the 1970s echoes the work of Kalecki ([1954]2009) who conclusively argued that "The degree of monopoly has a general tendency to increase in the long run and thus to depress the relative share of wages in income..." (ib., p.30) The most profound factor driving monopoly power is the promotion of giant corporations and the concomitant price fixing. The substantial share in an industry's output of such a firm implies that (i) its price can significantly influence the average price, and (ii) other firms will follow since their price is a function of the average price. As the game of setting the price at a higher level than otherwise is also played by other big firms, the end result is a rise in the degree of monopoly.

Here is a synopsis of Kalecki's theory on price formation in an industry and the relation between the degree of monopoly and the wage share. Let the price of the firm, $p$, be a function of the unit prime cost (i.e. wages and the cost of primary products), $u$, and the weighted average price of all firms $(\bar{p}): p=m u+n \bar{p}$, where the coefficients $m$ and $n$ are associated with price-fixing and reflect what Kalecki calls the degree of monopoly of the firm's position. Consequently, the increase of $\frac{m}{1-n} \equiv k$ captures a higher degree of monopoly. Expanding the analysis from the firm level to the industry level, it can be shown that the average price is proportionate to the average unit cost for a given degree of monopoly: $\bar{p}=k \bar{u}$. That is, a higher degree of monopoly implies that the average price rises relatively to the average unit prime cost.

The ratio of proceeds to prime costs in an industry can be linked with the relative share of wages in value added as follows:

$$
\text { proceeds }=k(W+M)
$$

where $W$, and $M$ denote aggregate wages and the aggregate cost of materials, respectively. Subtracting the cost of materials from both sides of equation (2) leads to an expression of value added:

$$
\begin{aligned}
\text { value added } \equiv \text { proceeds }-M & =k(W+M)-M \Rightarrow \\
\text { value added }-W & =(k-1)(W+M) \Rightarrow \\
\text { value added } & =W+(k-1)(W+M) .
\end{aligned}
$$

In the light of equation (3), the relative share of wages in the value added of the 
industry can be captured neatly as

$$
\begin{aligned}
\omega=\frac{W}{\text { value added }} & =\frac{W}{W+(k-1)(W+M)} \Rightarrow \\
w & =\frac{1}{1+(k-1)(j+1)},
\end{aligned}
$$

where $j$ is the ratio of the aggregate cost of materials to the wage bill (ib., p.28). Clearly, a higher degree of monopoly $(k)$ leads to a lower wage share. In effect, Kalecki unveils the connection between the evolution of the labour income share and the degree of monopoly with an invaluable theoretical clarity.

It is worth noting that in the last thirty years or so we are experiencing an old power struggle between competition and monopoly in new clothes with a well manifested outcome: the systemic creation and preservation of inequality and business concentration via Call-Put policy options, in the pure sense of "unwarranted" rights. ${ }^{5}$

\subsection{Wage Gap, Frictional Growth and the Kalecki Insight}

Challenging the widely accepted perspective that the wage-productivity gap vanishes in the long run and thus the labour income share is neutral to labour demand, Karanassou and Sala (2011) considered a stylised wage-setting equation depicting the adjustment of wages to productivity movements:

$$
w_{t}=\alpha_{1} w_{t-1}+\left(1-\alpha_{1}\right) p r_{t}
$$

where $w_{t}$ denotes log real wage, $p r_{t}$ is labour productivity (in logs), and the autoregressive parameter is $0<\alpha_{1}<1$. Higher order lags, other explanatory variables (i.e. unemployment and wage-push factors, such as benefits and union power), and the error term are ignored for simplicity. Wage dynamics in equation (5) can be justified in terms of wage/price staggering (Taylor, 1979, 1980), or wage aspirations (e.g. Ball and Moffitt, 2002), or the reconciliation between the empirical Phillips-curve and theoretical wage-curve relations (Blanchard and Katz, 1999).

It should be further pointed out that the dynamic wage-setting (5) is in line with the dominant view of a unitary elasticity of wages with respect to productivity in the long

\footnotetext{
${ }^{5}$ Hatgioannides and Karanassou (2011) unwind the Call-Put policy options, facilitated by the seventies invention of FIAT money, and explain how they have engineered the dysfunctional market system of a Warrant Economy. The latter is the most recent phase of the ever transforming power base of monopoly capitalism to anihillate competition. Seen from this angle, financialisation is merely a symptom of CallPut provisions, a business situation that advances multi-source profits and "optimises" in the Warrant Economics cocoon of market activity.
} 
run. This becomes apparent when we rewrite it as

$$
w_{t}=\underbrace{p r_{t}}_{\text {'trend' or steady-state }}-\underbrace{\frac{\alpha_{1}}{1-\alpha_{1}} \Delta w_{t}}_{\substack{\text { 'cycle' if long-run growth }=0 \\ \text { 'frictional growth' otherwise }}},
$$

where $\Delta$ is the first difference operator. If growth is zero, then wages move in line with productivity, but the higher the growth is the more they trail productivity. Taking first differences, and assuming that the growth rate of productivity stabilises with the passage of time, we obtain the conventional benchmark that the growth rate of real wages is equal to productivity growth in the long run.

In contrast to the standard dictum, and whilst maintaining the assumption of a unitary long-run elasticity of wages with respect to productivity, Karanassou and Sala (2011) argue that productivity growth affects wages at all time horizons due to frictional growth. The latter is a phenomenon generated by the interplay of lags and growth in the wage setting process, the implication of which is that the growth of 'wage aspirations' does not eventually catch up with productivity growth.

Consequently, equation (6) conveys the following key point: the real wage can be decomposed into two terms, the 'trend' and frictional growth of the model. If productivity does not grow in the long run, the real wage will stabilise in the long run. In this case frictional growth is zero and the second term of equation (6) describes the 'cyclical' component of real wages. Put differently, the steady-state and long-run versions of dynamic wage setting coincide only in the utopian scenario of zero growth and/or no dynamics.

We highlight the fact that, since the long-run elasticity of the real wage with respect to productivity is unity regardless of whether frictional growth is zero or not, the focus of economists on elasticities implied that the phenomenon of frictional growth would be ostracised from the analysis of macro-labour models. This took place despite the plausibility of a dynamically growing environment that gives rise to the interplay of frictions and growth.

\section{The Kalecki Insight}

Traces of the interplay between lags and growth can be detected in the theory of economic dynamics of Kalecki ([1954]2009): "It is known that prices of raw materials undergo larger cyclical fluctuations than wage rates. The causes of this phenomenon can be explained as follows. Even with constant wage rates the prices of raw materials $(\mathrm{rm})$ would fall in a depression as a result of a slump in 'real' demand. Now, the cuts in money wages during a depression can never 'catch up' with the price of raw materials because wage cuts in turn cause a fall in demand and hence a new fall in the prices of primary products." (ib., 
p.24)

We endeavour to express analytically Kalecki's argument with a simple first-order dynamic equation, $w_{t}=\alpha w_{t-1}+(1-\alpha) r m_{t}$, and its reparameterisation:

$$
w_{t}=\underbrace{r m_{t}}_{\text {'trend' or steady-state }}-\underbrace{\frac{\alpha}{1-\alpha} \Delta w_{t}}_{\substack{\text { 'cycle' if long-run growth=0 } \\ \text { 'frictional growth' otherwise }}}
$$

In view of equation (7), let us interpret Kalecki's statement as [our additions in italics and in ()]: wages do not adjust fully to movements in the prices of raw materials $\left(r m_{t}\right)$ which would fall in a depression as a result of a slump in 'real' demand. Now, the cuts in money wages during a depression can never 'catch up' $\left(w_{t}=r m_{t}\right)$ with the price of raw materials because wage cuts in turn cause a fall in demand and hence a new fall in the prices of primary products (interplay between dynamics and the shift in the determinant).

We should remark that, for a variety of issues at the core of the economic spectrum, frictional growth has substantial implications, such as (i) the irrelevance of the natural rate as a long-run attractor of unemployment, and (ii) the existence of an inflationunemployment tradeoff in both the short and long run. ${ }^{6}$

\section{Personal Income Distribution}

From the trauma of the stagflating 1970s and the ensuing deregulation starting in the 1980s, to the roaring 1990s and up to the great moderation of the 2000s, the pillars of conventional wisdom in economic policy were established on the premises of low inflation, reasonably good and sustainable growth, and relatively low unemployment. Issues of inequality and distribution had been ostracised from the analysis of economic affairs as it was thought that they could be trivially resolved under the holy trinity of the above economic outcomes.

In the midst of the worst since the 1930s economic crisis, the alarming rise in unemployment and the significant numbers of foreclosures that sparked the protest against the rich-poor divide, the distribution issue resurfaces in the political scene after its long absence from the lexicon of mainstream economists.

\subsection{Measuring Inequality}

Figure 1 shows that inequality increased by $20 \%$ over the 1960-2009 period (from 0.36 in 1960 to 0.44 in 2009). Although our summary measure of the personal income distribution

\footnotetext{
${ }^{6}$ See, for example, Karanassou, Sala, and Salvador (2008), and Karanassou, Sala and Snower (2010).
} 
is the Gini coefficient, it is worth highlighting its differences from alternative measures of top income shares. The Gini ratio (or relative income) is constructed by the Census Bureau using internal Current Population Survey (CPS) data, while income trends in terms of top shares are obtained by the Internal Revenue Service (IRS) tax return data. ${ }^{7}$

CPS data measure pre-tax, post-transfer income, and exclude capital gains. In contrast, although the IRS data refer to pre-tax income, they exclude most transfer income (since the latter is generally not taxable) but include capital gains, stock options and bonuses. Survey data have been criticised for not being able to fully capture the top end of the distribution due to topcoding, undercoverage, and underreporting of top incomes. The availability of tax return data for longer time spans than survey data is a further attractive feature of the former. On the other hand, the Gini statistic has a twofold advantage: (i) it is a more comprehensive measure of inequality as it uses data on all incomes rather than just the richest end of the spectrum, and (ii) it includes many sociodemographic variables, since the CPS survey questions about income are broader than those on IRS tax forms. ${ }^{8}$

The typical interpretation of the Gini index is through the geometry of a Lorenz diagram plotting the cumulative population shares, from the poorest to the richest, against their cumulative income shares. It is the area between the Lorenz curve and the diagonal $\left(45^{\circ}\right)$ line as a ratio of the area below the diagonal (e.g. see Brewer et al., 2006, p.68). As the value of the Gini statistic increases from zero to one, the more unequal the income distribution becomes.

A more intuitive interpretation than the standard geometric one is given by Shorrocks (2005), where the Gini coefficient is portrayed as the division of a "pie" into two unequal shares. For example, a Gini value of 0.40 is obtained from the division of an aggregate economic pie worth $\$ 1$ into $90 \mathrm{c}$ and 10c. Presenting inequality as "a 2-way division of a pie in which one person gets 9 times the other is a powerful way of capturing the extent of income differences." Since the "fair" share in a 2-way division is 0.50 , the Gini value of 0.40 represents the excess share of the richest person (Gini $=0.90-0.50$ ).

\footnotetext{
${ }^{7}$ For a reconciliation of estimates from CPS and IRS tax data see the authoritative work by Burkhauser et al. (2012).

${ }^{8}$ The Gini ratio is most easily calculated from unordered size income, $x$, data as the 'relative mean difference', i.e., the mean of the difference between every possible pair of individuals divided by the mean size $\mu$ (http://www.wolframalpha.com/input/?i=gini+coefficient):
}

$$
\text { Gini }=\frac{\sum_{i=1}^{n} \sum_{i=1}^{n}\left|x_{i}-x_{j}\right|}{2 n^{2} \mu} .
$$




\subsection{Inequality Burst}

Although we use the Gini index to measure inequality, and although the issue of how closely top income shares track the Gini coefficient is far from being resolved, ${ }^{9}$ it is worthwhile to point out some dramatic results on the top end of the personal distribution spectrum that have dominated the debate in recent years.

The graphic evidence in Figure 2 shows that, since the late 1970s, income inequality has evolved in terms of an upward 'trend' rather than 'episodes' of falling/increasing inequality. In 2008 the top $1 \%$ appropriated $17.7 \%$ of the national income amounting to an increase of $111 \%$ since 1960, most of it arising after the second half of the eighties. Seen from the other side of the spectrum, the decreasing income shares of the bottom $99 \%$ reflect the continuing squeeze of the middle classes since the 1980s.

Piketty and Saez (2006) demonstrate that the last time the top percentile reached a value of around $18 \%$ was before WWI. More astounding is the observation by Saez (2010) that the top $0.01 \%$ in 2008 took in 5 percent of the national income, a level which until the late nineties had not been witnessed since 1928 (ib., Figure 3). Wolff and Zacharias (2006) further document that, over the 1982-2000 period, the share of the top percentile increased from $9.9 \%$ to a staggering $17.4 \%$, using the standard measure of money income, and from $14.1 \%$ to $20.1 \%$ using the their measure of wealth adjusted income. In a brief overview of trends in income inequality, Mankiw (2010) notes that since the mid-1970s the share of total income of the top $0.01 \%$ (i.e. those with annual income of more than $\$ 11$ million) has increased about sixfold.

Studying 'Top Incomes in the Long Run of History', Atkinson, Piketty, and Saez (2011) use the Pareto law for top incomes to obtain the (cumulative) distribution function for income $y$ and focus on what they refer to as the inverted Pareto coefficient, $\beta$. This is the ratio of average income $y^{*}(y)$ of individuals with income above $y$ to $y$. The authors argue that the coefficient $\beta$ has more intuitive economic appeal, since a higher $\beta$ means a fatter upper tail of the distribution. They find that "in the United States, the $\beta$ coefficient (estimated at the top percentile threshold and excluding capital gains) increased gradually from 1.69 in 1976 to 2.89 in 2007 as top percentile income share surged from $7.9 \%$ to $18.9 \%$ ". It is further noted that when capital gains are included, "the rise of the $\beta$ coefficient is even more dramatic, from 1.82 in 1976 to 3.42 in $2007 "{ }^{10}$

In the Financial Times (2008, October 29) we read that "Between 2000 and 2006 the US economy expanded by 18 per cent, whereas real income for the median working class dropped by 1.1 per cent ... Meanwhile, the top tenth saw an improvement of 32 per cent

\footnotetext{
${ }^{9}$ The study of Burkhauser et al. (2012) is particularly informative about the differences in estimated inequality trends that can arise from differences in the definition of income (and the way its distribution is summarised) or from differences in the data sources. Nevertheless, the focus of our work does not loose weight.

${ }^{10} \mathrm{Ib}$., Section 3, 'Pareto Interpolation'.
} 
in their incomes, the top 1 per cent a rise of 203 per cent the top 0.1 per cent a staggering gain of 425 per cent." Wolff and Zacharias (2006, p. 5) note that in 2004, the median net worth of the individuals in the Forbes 400 list was $\$ 1.5$ billion "as compared to the median net worth of $\$ 93,000$ for all other households."

As the increase in the share of the top percentile has been accompanied by the exceptional growth in top executives' pay relative to the salaries of employees, the issue of whether the so called "working rich"11 have replaced top capital owners (the "rentiers") at the top of the economic ladder is open to debate. For example, Wolff and Zacharias (2006) do not support this issue, whereas Piketty and Saez (2006) argue in its favour.

Interestingly, the Financial Times (2010, February 3) reported that "A packed session at the World Economic Forum in Davos...addressed the issue of executive compensation and the huge rise in the pay gap between chief executives and ordinary workers in their organisations. ...The best-paid person in a US company was paid about 40 times that of the worst-paid person a generation ago. Now the multiple is about 300. ...Asked whether the reason was that management had improved hugely; executives were underpaid in the past; their jobs were more onerous today, or whether executives had collectively exploited market power to raise their salaries, all of the members of the panel agreed that the last possibility was closest to the truth."

Apparently, the personal income distribution theme was forced to enter (for the first time) in the agenda of the World Economic Forum in Davos 2012, where the priority(!) of tackling growing inequality generated heated discussions (see the reports by BBC on 27/1, Bloomberg Businessweek 31/1, and others).

Figure 2. Top $10 \%$ and top $1 \%$ income shares in the US.

a. Absolute values.

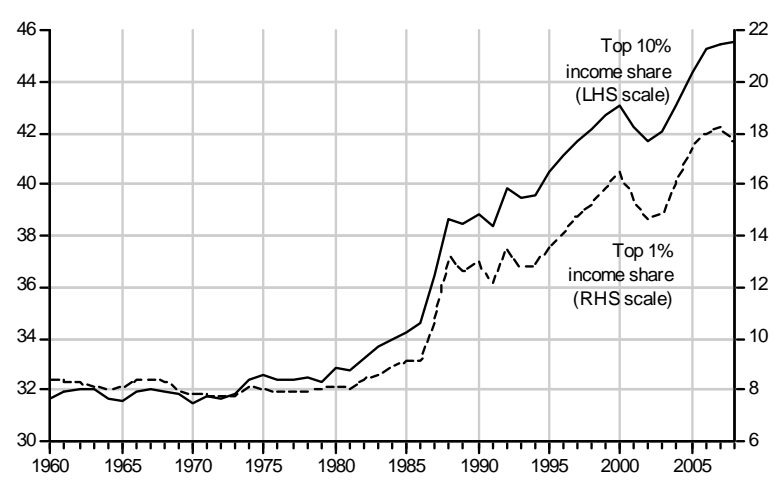

b. Index $100=1960$.

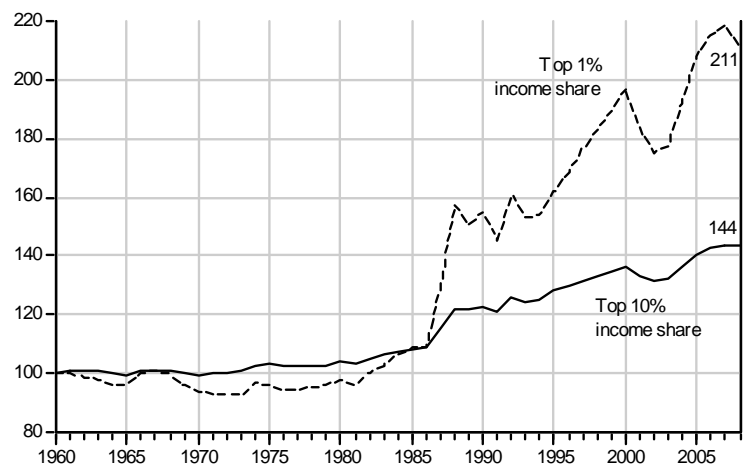

Source: Alvaredo et al. (2011).

\footnotetext{
11 "Forbes popularised this term. However, the magazine used it in the sense that the wealthiest Americans hold jobs rather than in the sense that the wealthiest depend mainly on labour income as their chief source of income." (Wolff and Zacharias, 2006, p. 12).
} 


\section{Modelling the Distributions}

To evaluate the driving forces that jointly determine the labour share and inequality, we postulate a system of equations for the functional and personal income distributions. Figure 3 sketches the system's key dimensions and illustrates the anatomy of the income distribution network.

Figure 3. Anatomy of the distribution nexus.

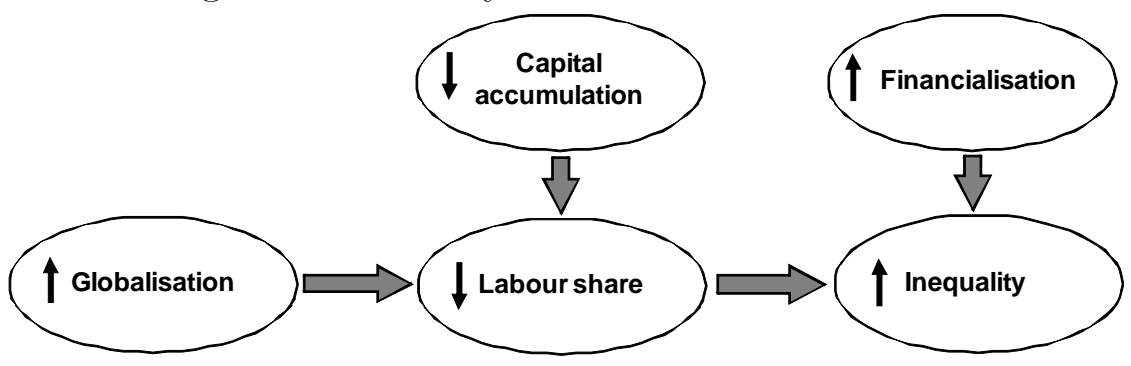

\subsection{Labour Share Equation}

We model the functional income distribution using a log-linear equation for the labour share, $l s_{t}$ :

$$
l s_{t}=a_{0}+\alpha_{1} l s_{t-1}-\alpha_{2} t r_{t}+\alpha_{3} k i_{t}+\text { "other" }+\varepsilon_{1 t},
$$

where $t r_{t}$ is trade, $k i_{t}$ denotes capital intensity, the $\alpha$ 's are positive parameters with $\alpha_{1}<1$, and $\varepsilon_{1 t}$ is a strict white noise error term. "Other" refers to business and household taxes, the growth rate of working age population as a proxy for migration flows, and lags of the explanatory variables. (Variables are defined in Table 1.) The autoregressive element in specification (8), typical in dynamic time series equations, controls for the empirical relevance of labour adjustment costs in the model.

Capital intensity (i.e. the capital-output ratio) was introduced as a major factor in the labour share equation by Bentolila and Saint Paul (2003). A positive elasticity between the two variables $\left(\alpha_{3}>0\right)$ indicates that labour and capital are complements (ib., p.22). Although it is tempting to interpret capital intensity as a variable driven by technology, Stockhammer (2009) is right to note that, from a Keynesian perspective, capital accumulation "will be driven to some extent by changes in animal spirits that are not primarily related to technology." (ib., p.31)

Capital intensity is also a driving force of the labour share equations in Milberg and Winkler (2010b), and Cecci and García-Peñalosa (2010), albeit the latter use capital per worker to capture capital intensity. Capital intensity is also considered by Milberg and Winkler (2010a) as a determinant in their profit share equation (in effect, the profit share is one minus the labour share).

Another major factor in the wage gap evolution is trade (or the degree of openness), which is commonly interpreted as a proxy for the central aspects of the globalisation 
process (e.g. IMF, 2007). Contrary to the prediction of Heckscher-Ohlin theory, it is widely accepted in the empirical literature that trade openness exerts a negative influence on the labour share.

Financialisation is the third and final key factor in the unraveling of the distributional nexus. Our point of view is that, while it affects directly the personal income distribution (see below), it enters indirectly the functional income distribution via the capital intensity factor. Following the reasoning in the literature on the negative effect of financialisation on real investment (e.g. Orhangazi, 2008), it can be argued that capital accumulation is the transmission channel of financialisation to the labour market (González and Sala, 2011).

\subsection{Gini Coefficient Equation}

As in Karanassou and Sala (2012), we examine the inequality factors with a log-linear model along the lines of the reduced form inequality equation in Checci and GarcíaPeñalosa (2010). Our autoregressive distributed lag model for income inequality has the following form:

$$
\operatorname{gini}_{t}=\beta_{0}+\beta_{1} g i n i_{t-1}-\beta_{2} l s_{t}+\beta_{3} f p_{t}+\text { "other" }+\varepsilon_{2 t},
$$

where gini $_{t}$ is the Gini coefficient (in logs), $f p_{t}$ denotes financial payments (the sum of dividends and interests as percent of corporate profits), and the $\beta$ 's are positive parameters with $\beta_{1}<1$. "Other" refers to direct and indirect taxes, and lags of the various determinants, and $\varepsilon_{2 t}$ is a strict white noise error term.

Blinder and Esaki (1978) introduced the approach of regressing the share of the $i^{\text {th }}$ quintile of the income distribution on the overall unemployment rate. Here, rather than a "group" perspective on inequality of the $i^{\text {th }}$ income share regressand, we have an aggregate perspective on inequality through regression (9). The Gini statistic captures inequality by measuring the allocation of income in (real) monetary terms to the various groups of agents. Therefore, wages, benefits, rewards to capital or labour, and institutions that facilitate such rewards are legitimate candidate determinants in a Gini regression. On one hand, having unemployment as an additional driving force in the model carries the risk of blurring the results. ${ }^{12}$ On the other, the effect of unemployment on inequality can be satisfactorily addressed by examining the relationship between the various income classes and the existence of unemployment à la Blinder and Esaki (for example, see Mocan, 1999).

It is widely understood that higher corporate profits as a share of national income lead

\footnotetext{
${ }^{12}$ Consider, for example, the Gini equation of Checchi and García-Peñalosa (2010). As the negative and insignificant unemployment coefficient using OLS and IV (Table 4, p. 428) becomes positive and significant with 3SLS (Table 5, p. 431), it is hard to justify such a u-turn of the estimates on the grounds of endogeneity and cross-equation correlation alone.
} 
to (i) higher investment and (ii) the engagement of non-financial businesses in financial markets (e.g. due to fees income), i.e. the 'financialisation' of the industry (Stockhammer, 2004; Milberg and Schöller, 2008; Milberg and Winkler, 2010a, among others). Recognising the link between corporate profits and financialisation, the finding that financial payments have a positive impact on the Gini coefficient implies that financialisation has a "direct" adverse effect on inequality. For an in-depth analysis of an intricate cobweb of institutional policy options that distort competition and accelerate economic concentration, and the systemic exploitation of inequality via novel and toxic forms of securitisation see Hatgioannides and Karanassou (2011).

\section{Estimated Model}

We need to point out that our investigation of the two-equation model (8)-(9) is in the context of the chain reaction theory (CRT) framework that is led by the bidirectional feedback between a prior viewpoint (or theory) and an observations-driven analysis. ${ }^{13}$ As such, our modelling approach is not subject to the so-called theoretical versus datadriven debate. Put differently, our macroeconometric methodology aims at exploring the symbiotic relationship of theory and evidence, rather than bridging the "gap" between the two through some sort of reverse engineering.

Our econometric application follows the autoregressive distributed lag (ARDL) approach, also known as bounds testing. The ARDL procedure, developed by Pesaran (1997), Pesaran and Shin (1999), and Pesaran, Shin and Smith (2001), has the advantage of yielding consistent short- and long-run estimates irrespective of whether the regressors are I(1) or I(0). Since an ARDL equation can be reparameterised in error-correction form and its long-run solution can be interpreted as the cointegrating vector of its variables, the ARDL procedure can be viewed as a rigorous alternative to the standard integration/cointegration techniques.

\section{$5.1 \quad$ Data}

We use annual observations over the 1960-2009 period obtained from the US Federal Reserve (data on dividends, interests, and corporate profits), the European Commission Ameco database (data on total net capital stock), and the OECD Economic Outlook (rest of variables). Time series data on income inequality are supplied by the Census Bureau

\footnotetext{
${ }^{13}$ The 'chain reaction' epithet flags the crucial role of impulse response functions in CRT model building. For a comprehensive discussion of the key features of chain reaction theory (CRT) models, simultaneous equations (SE), and vector autoregressions (VARs), and their main disparities, see Karanassou and Sala (2010, Section 3). The authors argue that the CRT provides an improvisation and synthesis of the SE and VAR methodologies. For the contribution of the 'chain reaction' analysis to unemployment and Phillips curve models see Karanassou, Sala and Snower (2010).
} 
and correspond to gini ratios for family household income. ${ }^{14}$ Our financialisation variable, measured by (net) interests and dividends as a percent of pre-tax profits of non financial corporations $(f p)$, accommodates sufficiently the two-sided role of financialisation. On one hand, the financial receipts crowd out the incentive of corporate management for real investment and, on the other, the financial payouts drain its funds (retained earnings) for real investment (González and Sala, 2011).

Table 1 describes the variables used in the selected specifications of the labour share and inequality equations. ${ }^{15}$

Table 1. Definitions of variables.

\begin{tabular}{ll|ll}
\hline \hline & & & \\
$l s$ & labour share $(=w-p r)$ & $t r$ & (exports + imports)/GDP \\
$w$ & real compensation per employee & $\tau^{h}$ & (direct taxes on households)/GDP \\
$p r$ & labour productivity $(=y-n)$ & $\tau^{b}$ & (direct taxes on business)/GDP \\
$n$ & employment & $z$ & working-age population \\
$g i n i$ & gini coefficient & $\tau^{p}$ & fiscal progressivity \\
$f p$ & financial payments= $\frac{\text { dividends }+ \text { interests }}{\text { corporate profits }}$ & & $=\frac{\text { total direct taxes }}{\text { indirect }+ \text { payroll taxes }}$ \\
$k i$ & capital intensity (capital stock/GDP) & $\Delta$ & difference operator \\
\hline \hline
\end{tabular}

Note: $\quad$ Variables are in logs unless otherwise indicated.

Sources: OECD Economic Outlook, European Commission, US Federal Reserve, US Census Bureau.

As in Karanassou and Sala (2011, 2012), we follow the European Commission methodology in their Ameco database and compute the adjusted labour share as

$L S=\frac{\text { total compensation/dependent employment }}{\text { GDP at factor costs/total employment }}=\frac{\text { total compensation }}{\text { GDP at factor costs }} \frac{\text { total employment }}{\text { dependent employment }}$

In this way, total labour compensation includes both dependent and self-employment compensation, and GDP excludes taxes and subsidies, which are not a component of generated income and need to be excluded from the calculation of the labour income share. Once the labour share is computed, we retrieve the average wage per employee (including self-employment) as $W=\frac{L S * Y}{N}$, where $N$ is total employment and $Y$ is the standard measure of GDP at market prices. Note that $w, n, y$, and $l s$ (defined in Table 1 ) are the log counterparts of $W, N, Y$ and $L S$. It follows that the labour share, $l s=w-p r$, can also be interpreted as the wage-productivity gap.

\footnotetext{
${ }^{14}$ (www.census.gov/hhes/www/income/data/historical/inequality). It is important to point out that our choice of the Gini time series data we use is restricted by their availability. Income for family households has a longer time span than the one for total households, which can be abtained only since 1967. Also note that both household series are available for money income rather than equivalised income.

${ }^{15}$ Although we have worked with an extended dataset (including competitiveness, union density, and benefits) we only report the estimates of variables entering the selected specifications.
} 


\subsection{Results}

Tables 2 and 3 present our estimates of the labour share and Gini equations, respectively, from 1962 to 2009. Although our empirical approach is a general to specific one, for expositional purposes, we first present the basic autoregressive equation E1 and then sequentially add the control variables. This allows the equation to progressively increase its explanatory power, reduce the standard errors of the regression, and minimise potential biases from omitted variables. Equations E6 and E7 in Table 2, and E5 and E6 in Table 3, display the selected specifications of the model by estimated by ordinary least squares (OLS) and three stage least squares (3SLS) to accommodate endogeneity and cross-equation correlation. These specifications have been selected by the optimal laglength algorithm of the Schwartz information criterion, and pass the standard misspecification tests - for residual autocorrelation, normality, linearity, and heteroskedasticity and the cusum and cusum ${ }^{2}$ structural stability tests.

\subsubsection{Labour Share Estimates}

The first exogenous variable appearing in Table 2 (see equation E2) is trade, or the degree of openness. It has the expected negative sign, which is robust across specifications. Working-age population is not significant in levels and clearly enters as a (log) difference. The growth of this variable implies that there is no long-run relationship between the labour share and (the level of) working-age population.

In model E4 we add capital intensity, a crucial factor in the evolution of the wageproductivity gap. As shown in Bentolila and Saint-Paul (2003), a positive coefficient of this variable, which is what we find, reflects the complementarity between labour and capital. The authors argue (ib., p.24) that "...as long as labor is paid its marginal product, there should be a one-for-one relationship between the labor share and the capital-output ratio..." We estimate a long-run capital intensity elasticity of $0.35\left[=\frac{0.14}{(1-0.60)}\right]$, which does not differ much from the 0.24 value obtained by Bentolila and Saint-Paul using a different sample, database, and estimation technique.

In equation E5 direct taxes on business have the expected negative sign on account of their negative influence on employment (which is in the numerator of the labour income share ratio). Finally, our preferred specification is equation E6. As expected, direct taxes on households affect the wage-productivity gap positively, which signifies their role as a wage-push factor (recall that wages are also in the numerator of the labour share). 


\section{Gini Estimates}

Looking at the Gini regressions in Table 3, the highly significant autoregressive coefficient of the inequality model decreases in value, as expected, as we augment the set of explanatory variables. Nevertheless, persistence remains high at around 0.8. The implication of high persistence is that the long-run effects of the determinants are much higher than the short-run ones.

Our selected specification, equation E5 estimated by 3SLS, measures the effects of the functional income distribution, financial profits, and fiscal progressivity on income inequality.

The labour share $(l s)$ evolution has a negative impact on the personal income distribution across all time horizons. On the other hand, financial payments $(f p)$ exert an upward pressure on inequality, contemporaneously and in the long run, while the negative effect of their change $(\Delta f p)$ dissipates rather fast. Finally, the higher the progressivity of the fiscal system $\left(\tau^{p}\right)$, the lower is inequality.

Table 2. Labour share equation. 1962-2009.

\begin{tabular}{|c|c|c|c|c|c|c|c|}
\hline \multicolumn{8}{|c|}{ Dependent variable: $l s_{t}$} \\
\hline & \multicolumn{6}{|c|}{ OLS } & \multirow{2}{*}{$\frac{3 \mathrm{SLS}}{[\mathrm{E} 7]}$} \\
\hline & {$[\mathrm{E} 1]$} & [E2] & [E3] & [E4] & [E5] & {$[\mathrm{E} 6]$} & \\
\hline$c$ & $\begin{array}{c}0.21 \\
{[0.195]}\end{array}$ & $\begin{array}{c}1.21 \\
{[0.018]}\end{array}$ & $\begin{array}{c}1.55 \\
{[0.001]}\end{array}$ & $\begin{array}{r}2.59 \\
{[0.022]}\end{array}$ & $\begin{array}{c}3.71 \\
{[0.001]}\end{array}$ & $\begin{array}{c}4.31 \\
{[0.000]}\end{array}$ & $\begin{array}{c}4.33 \\
{[0.000]}\end{array}$ \\
\hline$l s_{t-1}$ & $\begin{array}{c}0.95 \\
{[0.000]}\end{array}$ & $\begin{array}{c}0.70 \\
{[0.037]}\end{array}$ & $\begin{array}{c}0.61 \\
{[0.060]}\end{array}$ & $\begin{array}{c}0.66 \\
{[0.000]}\end{array}$ & $\begin{array}{c}0.58 \\
{[0.000]}\end{array}$ & $\begin{array}{c}0.60 \\
{[0.000]}\end{array}$ & $\begin{array}{c}0.60 \\
{[0.000]}\end{array}$ \\
\hline$t r_{t}$ & & $\begin{array}{c}-0.03 \\
{[0.038]}\end{array}$ & $\begin{array}{c}-0.03 \\
{[0.016]}\end{array}$ & $\begin{array}{c}-0.02 \\
{[0.015]}\end{array}$ & $\begin{array}{c}-0.03 \\
{[0.000]}\end{array}$ & $\begin{array}{c}-0.03 \\
{[0.003]}\end{array}$ & $\begin{array}{c}-0.03 \\
{[0.001]}\end{array}$ \\
\hline$\Delta t r_{t-1}$ & & & & $\begin{array}{c}0.14 \\
{[0.002]}\end{array}$ & $\begin{array}{c}0.18 \\
{[0.000]}\end{array}$ & $\begin{array}{c}0.17 \\
{[0.000]}\end{array}$ & $\begin{array}{c}0.17 \\
{[0.000]}\end{array}$ \\
\hline$\Delta z_{t}$ & & & $\begin{array}{c}1.34 \\
{[0.001]}\end{array}$ & $\begin{array}{c}1.02 \\
{[0.001]}\end{array}$ & $\begin{array}{l}1.39 \\
{[0.000]}\end{array}$ & $\begin{array}{c}1.26 \\
{[0.000]}\end{array}$ & $\begin{array}{c}1.26 \\
{[0.000]}\end{array}$ \\
\hline$k i_{t}$ & & & & $\begin{array}{c}0.06 \\
{[0.165]}\end{array}$ & $\begin{array}{c}0.10 \\
{[0.017]}\end{array}$ & $\begin{array}{c}0.14 \\
{[0.004]}\end{array}$ & $\begin{array}{c}0.14 \\
{[0.001]}\end{array}$ \\
\hline$\Delta k i_{t}$ & & & & $\begin{array}{c}0.38 \\
{[0.000]}\end{array}$ & $\begin{array}{c}0.32 \\
{[0.000]}\end{array}$ & $\begin{array}{c}0.29 \\
{[0.000]}\end{array}$ & $\begin{array}{c}0.29 \\
{[0.000]}\end{array}$ \\
\hline$\tau_{t}^{b}$ & & & & & $\begin{array}{c}-0.02 \\
{[0.003]}\end{array}$ & $\begin{array}{c}-0.02 \\
{[0.005]}\end{array}$ & $\begin{array}{c}-0.02 \\
{[0.002]}\end{array}$ \\
\hline$\tau_{t}^{h}$ & & & & & & $\begin{array}{c}0.02 \\
{[0.084]}\end{array}$ & $\begin{array}{c}0.02 \\
{[0.047]}\end{array}$ \\
\hline $\operatorname{Adj} . R^{2}$ & 0.927 & 0.932 & 0.947 & 0.968 & 0.974 & 0.975 & 0.975 \\
\hline St.e. & 0.011 & 0.011 & 0.009 & 0.007 & 0.007 & 0.006 & 0.006 \\
\hline Obvs. & 48 & 48 & 48 & 48 & 48 & 48 & 48 \\
\hline
\end{tabular}

Notes: p-values in brackets; instruments for the 3SLS estimation: $c, l s_{t-1}, g_{i n i} i_{t-1}$, $k i_{t}, k i_{t-1}, t r_{t}, t r_{t-1}, t r_{t-2}, z_{t}, z_{t-1}, f p_{t}, \tau_{t}^{b}, \tau_{t}^{h}, \tau_{t}^{p}$. 
Table 3. Gini equation. 1962-2009.

\begin{tabular}{|c|c|c|c|c|c|}
\hline \multicolumn{6}{|c|}{ "Dependent variable: gini $_{t}$} \\
\hline & \multicolumn{4}{|c|}{ OLS } & \multirow{2}{*}{$\frac{3 \mathrm{SLS}}{[\mathrm{E} 5]}$} \\
\hline & [E1] & [E2] & [E3] & {$[\mathrm{E} 4]$} & \\
\hline$c$ & $\begin{array}{c}0.01 \\
{[0.730]}\end{array}$ & $\begin{array}{c}0.97 \\
{[0.064]}\end{array}$ & $\begin{array}{l}0.65 \\
{[0.162]}\end{array}$ & $\begin{array}{c}0.98 \\
{[0.043]}\end{array}$ & $\begin{array}{r}0.98 \\
{[0.028]}\end{array}$ \\
\hline$g i n i_{t-1}$ & $\begin{array}{l}1.00 \\
{[0.000]}\end{array}$ & $\begin{array}{c}0.89 \\
{[0.000]}\end{array}$ & $\begin{array}{c}0.84 \\
{[0.000]}\end{array}$ & $\begin{array}{c}0.80 \\
{[0.000]}\end{array}$ & $\begin{array}{c}0.79 \\
{[0.000]}\end{array}$ \\
\hline$l s_{t-1}$ & & $\begin{array}{c}-0.25 \\
{[0.066]}\end{array}$ & $\begin{array}{c}-0.19 \\
{[0.128]}\end{array}$ & $\begin{array}{l}-0.28 \\
{[0.031]}\end{array}$ & $\begin{array}{l}-0.28 \\
{[0.019]}\end{array}$ \\
\hline$f p_{t}$ & & & $\begin{array}{c}0.02 \\
{[0.001]}\end{array}$ & $\begin{array}{c}0.01 \\
{[0.046]}\end{array}$ & $\begin{array}{l}0.02 \\
{[0.028]}\end{array}$ \\
\hline$\Delta f p_{t-1}$ & & & $\begin{array}{l}-0.03 \\
{[0.004]}\end{array}$ & $\begin{array}{l}-0.02 \\
{[0.010]}\end{array}$ & $\begin{array}{l}-0.02 \\
{[0.004]}\end{array}$ \\
\hline$\tau_{t}^{p}$ & & & & $\begin{array}{c}-0.05 \\
{[0.045]}\end{array}$ & $\begin{array}{l}-0.05 \\
{[0.032]}\end{array}$ \\
\hline$A d j . R^{2}$ & 0.969 & 0.970 & 0.977 & 0.979 & 0.979 \\
\hline St.e. & 0.015 & 0.015 & 0.013 & 0.012 & 0.012 \\
\hline Obvs. & 48 & 48 & 48 & 48 & 48 \\
\hline
\end{tabular}

Notes: see Table 2 .

Figure 1 shows that the fitted values of our two-equation model follow closely the time paths of the labour income share and the Gini coefficient.

Figure 3. Actual and fitted values.
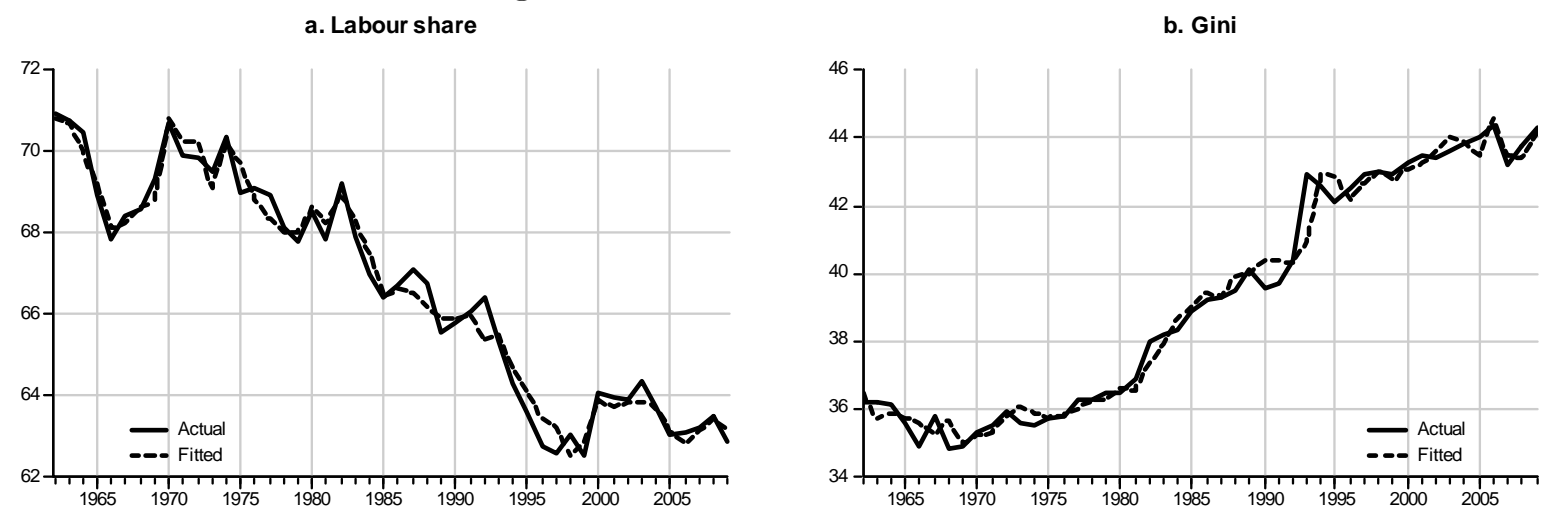

\section{Evaluating the Distributional Consequences}

Having established the statistical significance and adequacy of our model, we unveil its economic significance by evaluating the dynamic contributions of the shocks (or impulses) to the time paths of the labour share and inequality. "Shocks" are given shape in the chain reaction approach by the changes in the exogenous variables, rather than the residuals of the estimated model. ${ }^{16}$ In this way, the impulse response functions (IRFs) of the system

\footnotetext{
${ }^{16}$ The point raised by Blanchard (2009, p. 220) on the issue is notable: "The use of "shocks" is fraught with philosophical, but also with practical, difficulties: Technological shocks, animal spirits, changes in perceived uncertainty, etc. all have deeper causes, which themselves have even deeper causes, and so on."
} 
identify the impact of the actual changes in an exogenous factor on the evolution of the endogenous variables over a specific sample interval. ${ }^{17}$

In what follows we measure the distributional consequences of capital intensity, trade, and financial payments with counterfactual simulations. In particular, the estimated system (equations E7 in Table 2 and E5 in Table 3) is simulated by fixing each of these three main driving forces (one at a time) at their values at the start of the selected time intervals. The span of the simulation periods depends on the turning points of their time paths. In effect, simulating the responses of the endogenous variables answers the question: How have the ups and downs of these exogenous variables contributed to the evolution of the labour share and the Gini index?

Figure 4 plots the actual series (solid lines) together with the trajectories of their values fixed at the start of each selected period (dotted lines). The intervals 1982-1989, 1989-1991, 1991-2000, and 2000-2009 in Figure 4a clearly capture the falls and rises in capital intensity. In the case of the upward trend in trade (Figure 4b), and thus the absence of any turning points, the analysis is conducted for each decade. In contrast, financial payments exhibit a highly volatile upward trend until 1990, followed by spells of major swings spanning the 1991-1997, 1997-2001, 2001-2005, and 2005-2009 periods (Figure 4c).

Figure 4. Actual values and simulation intervals.

\section{a. Capital intensity}
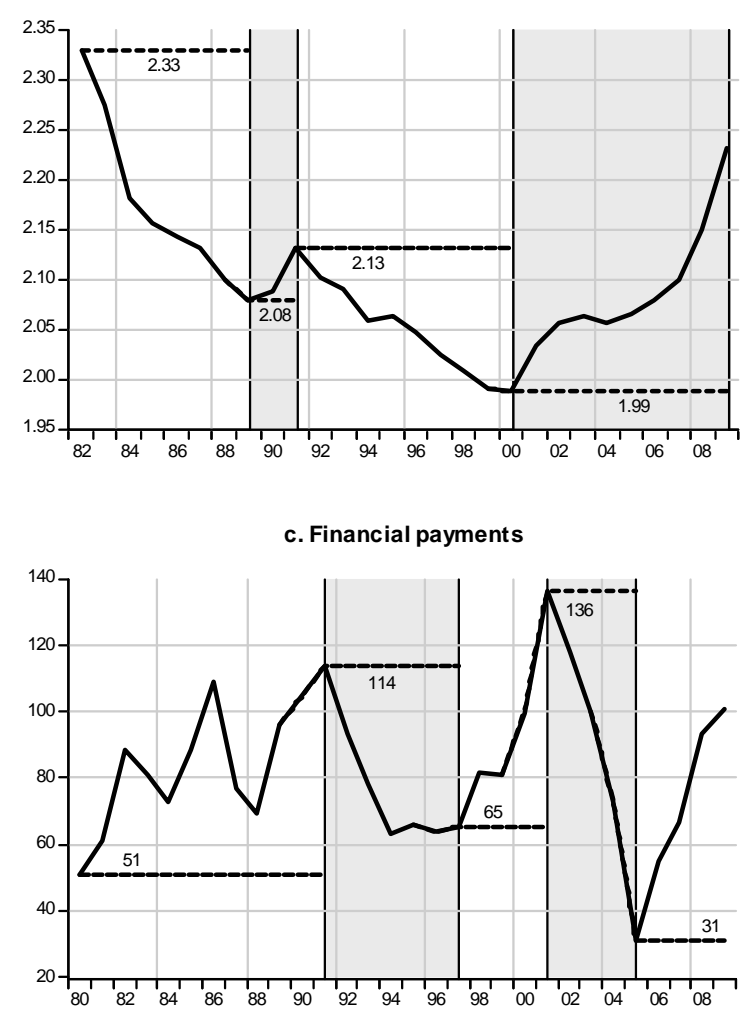

b. Trade

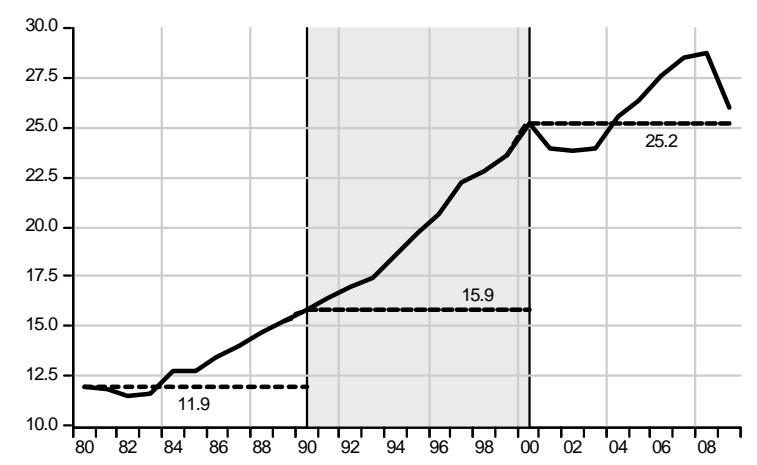

\footnotetext{
${ }^{17}$ The Appendix in Karanassou and Sala (2012) provides an analytic illustration of the dynamic accounting of contributions in the bivariate case under the static and AR(1) scenarios of the IRFs.
} 
Regarding our simulation results, note that (i) the first column in Figures 5 and 6 portrays the functional income distribution consequences of capital intensity and trade, respectively, and (ii) the second column pictures their consequences for the personal income distribution. In Figures 5-7 solid lines plot actual values, while dotted lines plot simulated ones.

\subsection{Capital Intensity Contributions}

The positive relation between the labour share and capital accumulation becomes apparent in Figures 5a-d. For example, consider the capital intensity contributions to the wage gap during the eigthies (Figure 5a). This simulation answers the question: "Had capital intensity remained at its 1982 value, instead of falling, what would have been the labour share level in 1989?"

The distance between the solid and dotted lines measures the dynamic contributions of capital intensity to the labour share time path. From 1982 to 1989, the decrease in the capital/GDP ratio explains $75.7 \%$ of the 3.7 percentage points (pp) drop in the labour share $\left(\frac{68.3-65.5}{69.2-65.5}=\frac{2.8}{3.7}=75.7\right)$. In a similar fashion, the decrease in capital intensity in the 1990s explains $81.0 \%$ of the $2.2 \mathrm{pp}$ widening of the wage gap (Figure 5c). The picture changes dramatically in the noughties (Figure $5 \mathrm{~d}$ ) as the increase in capital accumulation prevented the labour share from falling by an additional $2.8 \mathrm{pp}$.

Recall that capital intensity affects inequality indirectly via its effect on the labour share with the opposite sign, albeit of a lower magnitude. Figure $5 \mathrm{e}$ shows that its fall during the eighties explains $57.1 \%$ of the 2.1 pp increase in the Gini index $\left(\frac{40.1-38.9}{40.1-38}=\frac{1.2}{2.1}=57.1\right)$. In turn, the decrease in capital intensity during the nineties was responsible for about $25 \%$ of the $3.6 \mathrm{pp}$ deterioration of the personal income distribution (Figure 5c). On the other hand, had capital accumulation remained at its low value in 2000 for the rest of the decade, rather than increasing smoothly, the Gini would have increased by an extra 2.1 pp (Figure $5 \mathrm{~h}$ ), i.e. inequality would have been three times worse $\left(\frac{46.4-43.3}{44.3-43.3}=\frac{3.1}{1.0}\right)$.

\subsection{Globalisation Contributions}

As shown in equation E7 of Table 2, the globalisation process (defined by trade, $t r_{t}$ ) affects the labour share negatively in the long run and positively in the short run. This is captured by our simulations in Figures 6a-c. In the short- to medium-run years, the dotted lines are below actual levels, indicating that a lower degree of openness would have resulted in lower labour shares. But by the end of each decade, this positive effect either dissipates (Figure 6a), or reverses its sign in line with the negative long-run relation (Figures 6b-c). The latter figures show that the acceleration in the globalisation contributed to reduce the labour share (i) by less than $20 \%$ of its 2.7 pp decrease in the nineties, and (ii) by $90 \%$ 
of its $1.1 \mathrm{pp}$ decrease in the noughties. According to this finding, the labour share would have remained close to its year 2000 value had trade not increased in the noughties.

Interestingly, when looking at the globalisation consequences on the personal income distribution, we observe that in the medium run the higher degree of openness (through its labour share effect) lowered inequality. Unlike the labour share contributions of trade, the inequality contributions of trade within each decade are dominated by the positive short/medium-run effect of trade on the labour share. The negative long-run relation between trade and the labour share takes longer to manifest in the inequality equation because the labour share factor enters the Gini regression with a lag rather than contemporaneously.

Trade contributed to reduce the Gini index by $0.7 \mathrm{pp}$ in the eighties, by $0.4 \mathrm{pp}$ in the nineties, and by $0.7 \mathrm{pp}$ in the noughties (Figures $6 \mathrm{~d}-\mathrm{f}$ ). This may be related to the increasing share of cheap imports initially supplied by the emerging East-Asian countries and then by China. It can be argued that the negative medium-run impact of openness on inequality is one of the reasons that rising trade and the concomitant falling labour shares have been tolerated.

\subsection{Financialisation Contributions}

Unlike capital accumulation and globalisation, financialisation does not influence the functional distribution and has, instead, a direct impact on personal income. The estimated positive relation between the financial payments factor $\left(f p_{t}\right)$ and inequality is given in Table 3 and portrayed in Figure 7, where the first (second) column of the figure plots the simulations for the periods when financialisation is rising (falling).

Figure 7a shows that financial payments account for $40.6 \%$ of the increase in the Gini index over the 1980-1991 period; recall that the rest of this period's inequality increase (around 57.1\%) is explained by the decrease in capital intensity. In turn, the financialisation factor explains $83.3 \%$ of the increase in the Gini index during the 19972001 interval (Figure 7b). Regarding the increase in the second half of the noughties, had financial payments stayed as low as their 2005 value the Gini coefficient would have fallen back from 44 to around 43, its level at the start of the decade (Figure 7c).

In contrast, the slowdown in financial payments from 1991 to 1997 prevented the Gini index to increase by an extra $0.9 \mathrm{pp}$, almost an additional $28 \%$ of the actual increase (Figure 7d). Similarly, Figure 7e shows that the downfall of financial payments during the 2001-2005 years prevented the Gini index to further increase by $0.9 \mathrm{pp}$, a magnitude almost double its actual rise. 
Figure 5. Contributions of capital intensity.

a. To the labour share in 1982-1989

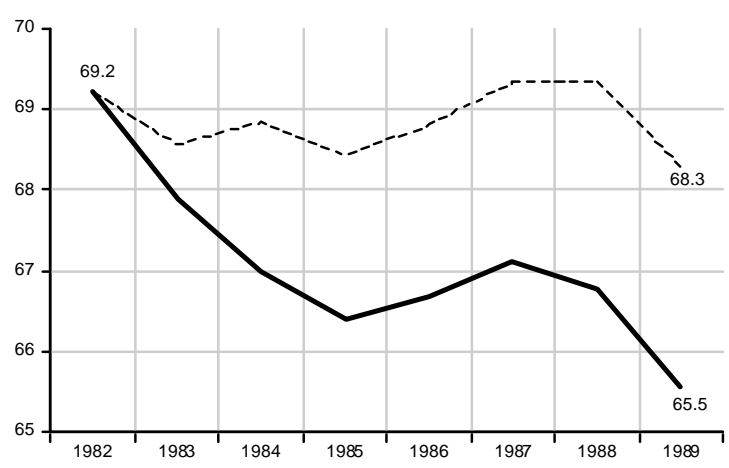

b. To the labour share in 1989-1991

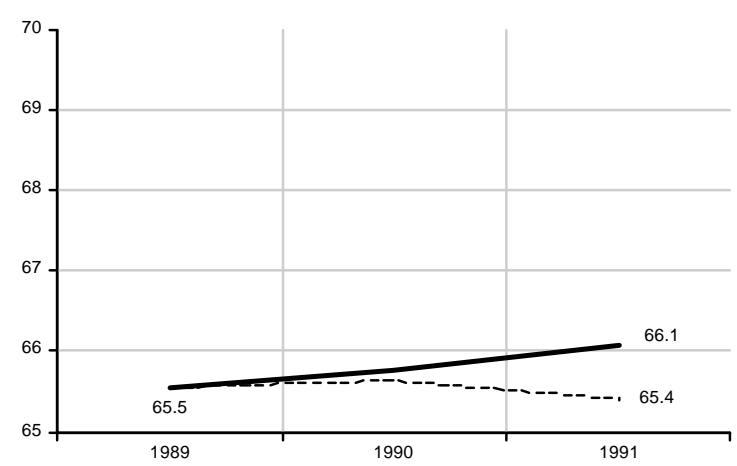

c. To the labour share in $1991-2000$

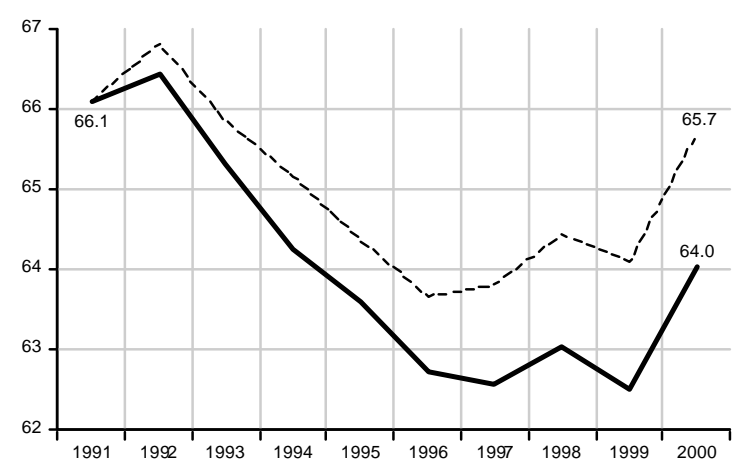

d. To the labour share in 2000-2009

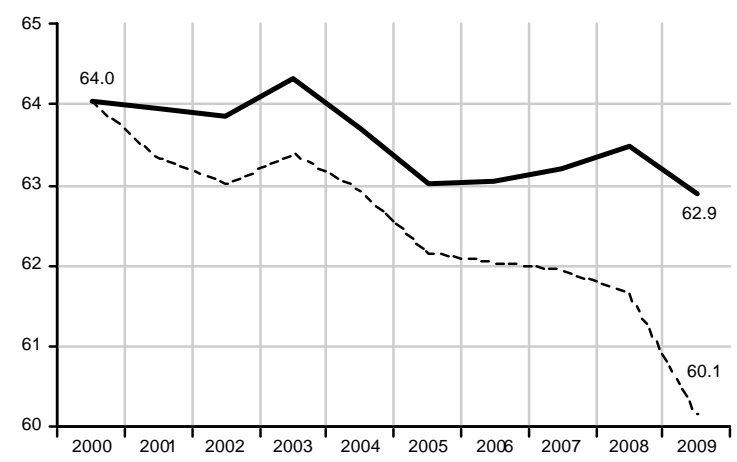

e. To the Gini index in 1982-1989

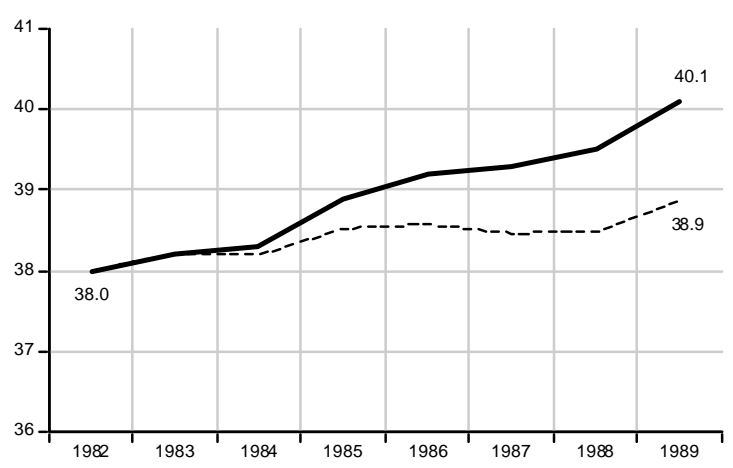

f. To the Gini index in 1989-1991

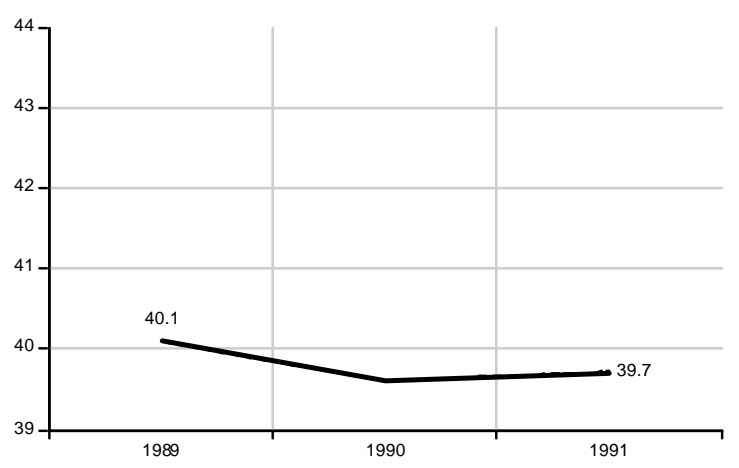

g. To the Gini index in 1991-2000

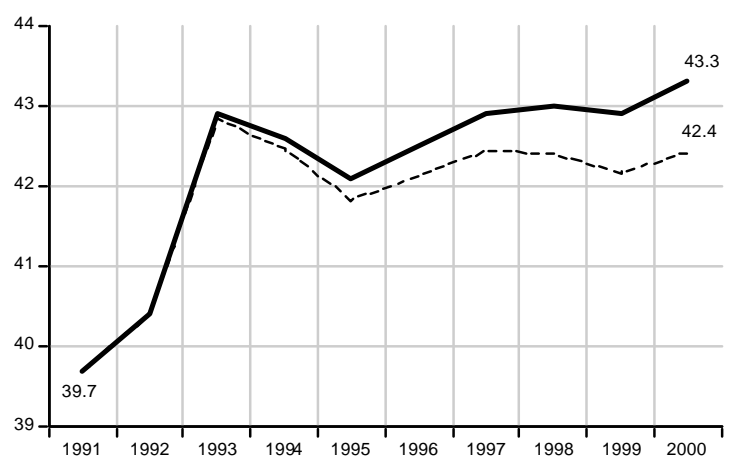

h. To the Gini index in 2000-2009

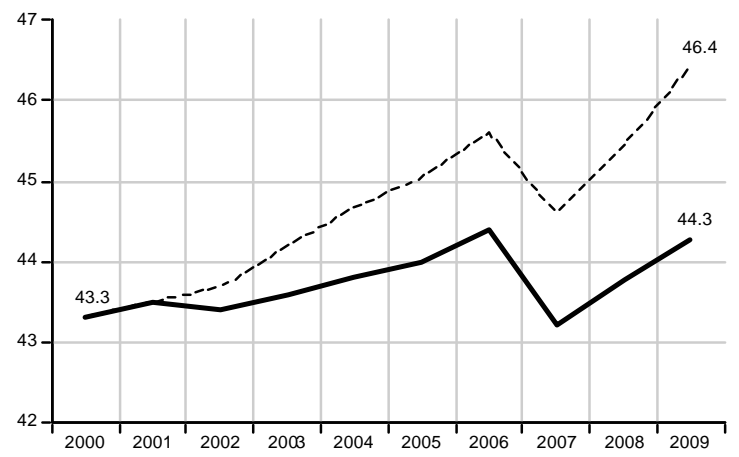


Figure 6. Contributions of trade.

a. To the labour share in the eighties

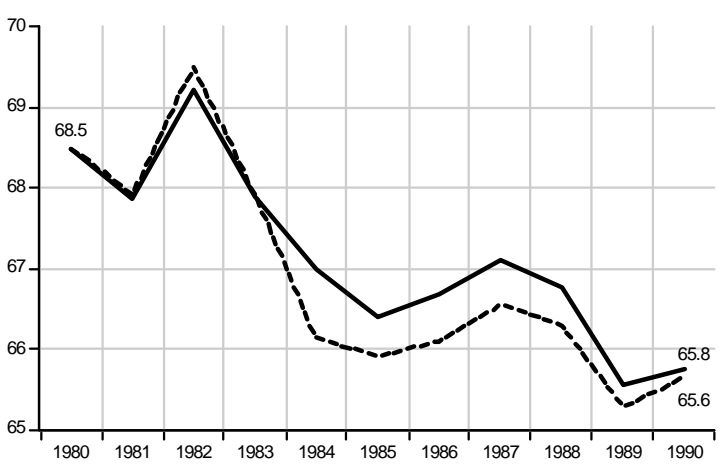

b. To the labour share in the nineties

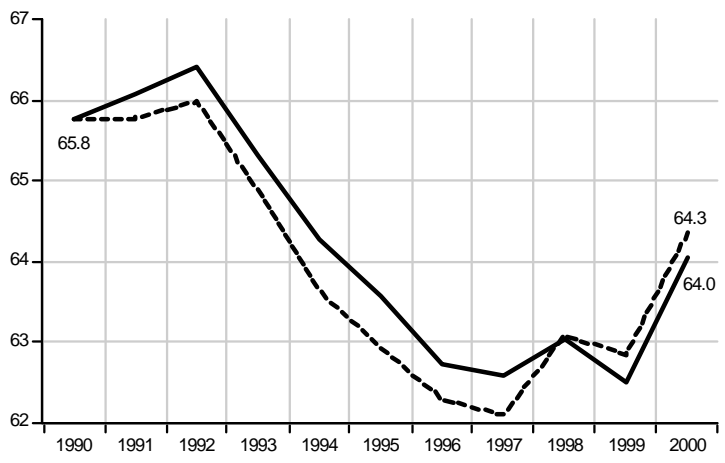

c. To the labour share in the noughties

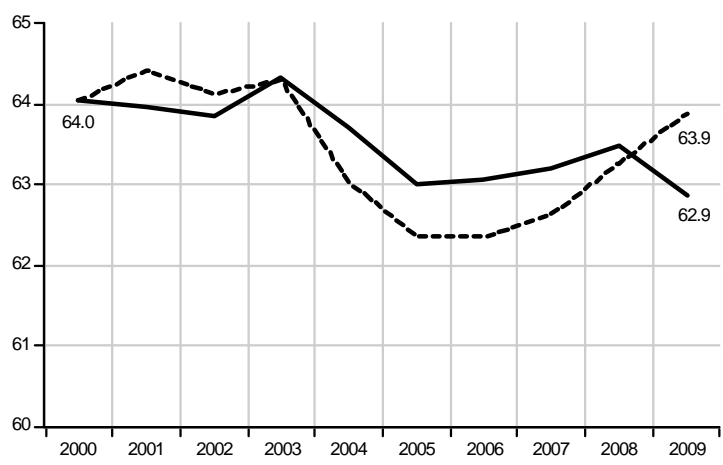

d. To the Gini index in the eighties

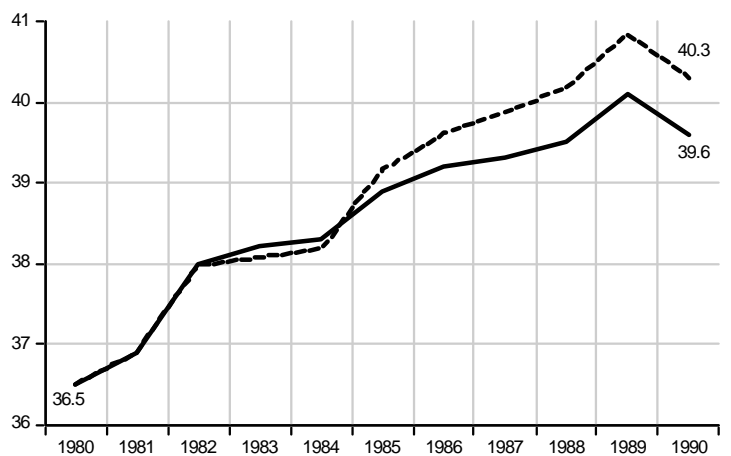

e. To the Gini index in the nineties

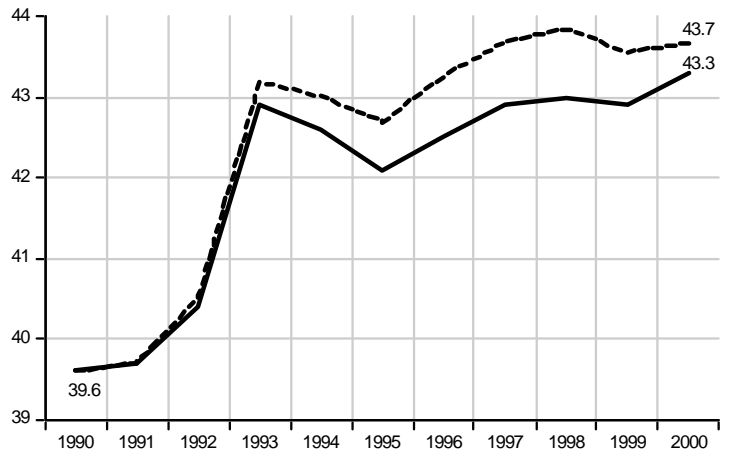

f. To the Gini index in the noughties

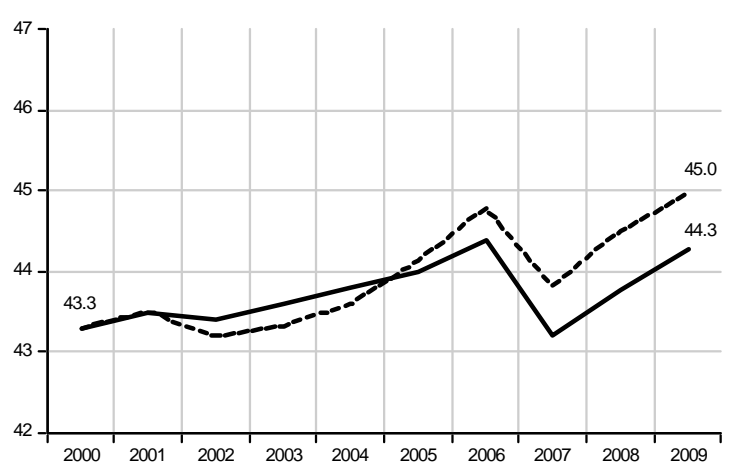


Figure 7. Contributions of financial payments to the Gini index.

a. 1980-1991

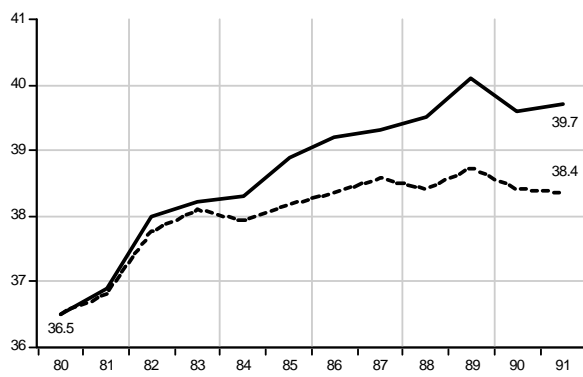

b. $1997-2001$

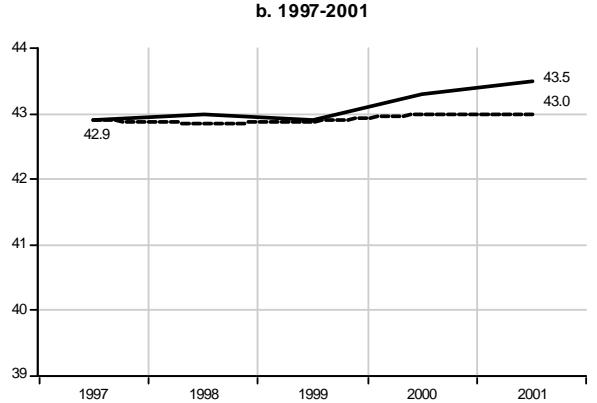

c. 2005-2009

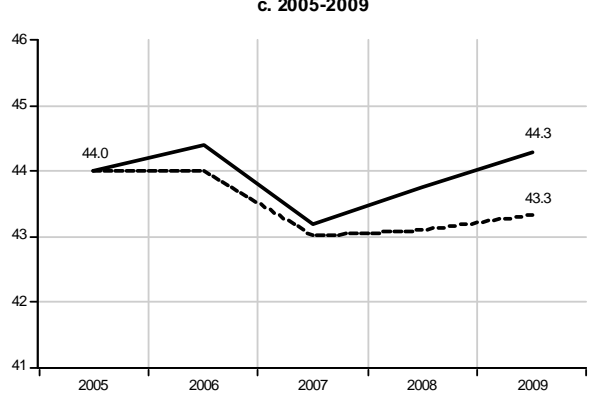

d. 1991-1997
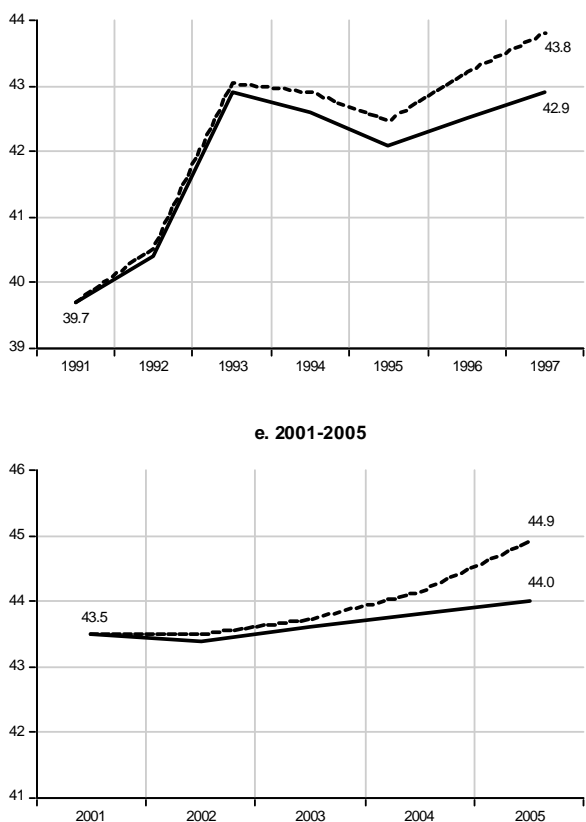

\section{Conclusions}

This paper explored the role of the wage-productivity gap in the income distribution nexus. The determining factors of the labour share and inequality were jointly identified with a two-equation model, where (i) the personal income distribution mainly depends on the labour share and financialisation, and (ii) the functional income distribution is driven by capital accumulation and globalisation, among other things. Emphasis was placed on the argument that the transmission channel of financialisation to the functional income distribution is through the capital intensity factor in the labour share equation.

Estimating the ARDL selected specifications of the system with 3SLS over the 19602009 period in the US, we documented (i) the positive impact of financial payments and the negative impact of the labour share on inequality; and (ii) the positive effect of capital intensity and the negative effect of trade on the labour share. Measuring the chain reactions of the (endogenous) labour share and Gini variables to the shocks in the system, we evaluated the distributional consequences of capital accumulation, globalisation and 
financialisation.

Our counterfactual simulations indicated that the most significant contributor to the labour share trajectory in the eighties was the capital intensity factor, accounting for around $76 \%$ of its fall. The picture changed dramatically by the noughties: it was the acceleration in the trade factor that contributed to $90 \%$ of the $1.1 \mathrm{pp}$ fall in the labour share, while the rise in capital accumulation prevented it from falling by an extra $2.8 \mathrm{pp}$.

Regarding inequality, both capital accumulation and globalisation affect the Gini equation indirectly, via the labour share equation, with the reverse sign. The capital intensity decrease explains about $57 \%$ of the increase in the Gini index in the eighties, and $25 \%$ in the nineties. On the other hand, inequality would have been three times worse had capital accumulation not increased after 2000. In terms of globalisation, the higher degree of openness contributed to ease inequality, albeit by less than $1.0 \mathrm{pp}$ in each decade.

Finally, although financialisation does not influence the functional income distribution, it has a direct impact on personal income and plays a key role in the inequality developments. Our findings indicate that financial payments accounted for about $40 \%$ of the increase in the Gini index during the eighties, and $83 \%$ of its increase over the 1997-2001 interval. Notably, had financialisation not increased in the second half of the noughties, inequality would have fallen back to its level at the start of the decade.

In the precarious post-2008 era of high or rising unemployment rates and quite tense socioeconomic phenomena, looking at income distribution issues through the lens of the wage-productivity gap could enlighten economic policy. In a previous stage of our enquiry we put forward the concept of the inequality-employment ratio of labour share elasticities as a barometer of economic pressure, signposting the degree of worsening inequality vis-a-vis job creation. Having now identified capital accumulation, globalisation, and financialisation as driving forces of the income distribution network, we endeavour to examine their impact on the labour share barometer in future work.

\section{References}

[1] Alvaredo, F., Atkinson A. B., Piketty T., and E. Saez (2011). The World Top Incomes Database: http://g-mond.parisschoolofeconomics.eu/topincomes, 23/11/2011.

[2] Atkinson, A.B., Piketty T., and Saez E. (2011): "Top Incomes in the Long Run of History," Journal of Economic Literature, vol. 49, 3-71.

[3] Bentolila, S. and Saint-Paul, G. (2003): "Explaining movements in the labor share", Contributions to Macroeconomics, vol. 3 (1), Article 9.

[4] Bhaduri, M. and Marglin, S. (1990): "Unemployment and the real wage: the economic basis for contesting political ideologies", Cambridge Journal of Economics, vol. 14, 375-393. 
[5] BIS (2009): "Household debt: implications for monetary policy and financial stability", Bank for International Settlements, BIS Papers No 46.

[6] Blanchard, O.J. (2009): "The State of Macro", Annual Review of Economics, vol. 1, pp. 209-228.

[7] Burkhauser, R.V., Feng S., Jenkins, S.P., and J. Larrimore (2012): "Recent Trends in Top Income Shares in the USA: Reconciling Estimates from March CPS and IRS Tax Return Data", Review of Economics and Statistics, forthcoming.

[8] Checchi, D. and C. García-Peñalosa (2010): "Labour Market Institutions and the Personal Distribution of Income in the OECD", Economica, vol. 77, pp. 413-450.

[9] Financial Times (2008): "Stuck in the Middle" by Edward Luce, October 29.

[10] Financial Times (2010): "Mind the Gap" by Chris Giles, February 3.

[11] Foster J. B., McChesney R. W., and R. J. Jonna (2011). "Monopoly and Competition in Twenty-First Century Capitalism", Monthly Review, 62 (11), 1-23.

[12] Giovannoni, O. (2010): "Functional Distribution of Income, Inequality and the Incidence of Poverty: Stylized Facts and the Role of Macroeconomic Policy", The University of Texas Inequality Project, UTIP Working Paper No. 58.

[13] González, I., and H. Sala (2011): "Macroeconomic consequences of the U.S. financialisation process: lower capital accumulation, higher unemployment", mimeo.

[14] Hatgioannides, J., and M. Karanassou (2011): "Warrant Economics, Call-Put Policy Options and the Fallacies of Economic Theory", IZA Discussion Paper 6251, Bonn.

[15] IMF (2007): "The globalization of labor", World Economic Outlook, April, IMF: Washington.

[16] Kalecki, M. ([1954]2009). "Theory of Economic Dynamics", Monthly Review Press Classics, Allen \& Unwin, New York.

[17] Karanassou M., and H. Sala (2010): "The US Inflation-Unemployment Tradeoff Revisited: New Evidence for Policy Making", Journal of Policy Modeling, 32, 758-777.

[18] Karanassou, M., and H. Sala (2011): "The Role of the Wage-Productivity Gap in Economic Activity", mimeo.

[19] Karanassou, M., and H. Sala (2012): "Inequality and Employment Sensitivities to the Falling Labour Share", Economic and Social Review, forthcoming.

[20] Karanassou M., Sala H., and P. F. Salvador (2008): "Capital Accumulation and Unemployment: New Insights on the Nordic Experience", Cambridge Journal of Economics, 32, 977-1001.

[21] Karanassou M., Sala H., and D. J. Snower (2010): "Phillips Curves and Unemployment Dynamics: A Critique and a Holistic Perspective", Journal of Economic Surveys, vol. 24, $1-51$. 
[22] Milberg, W. and D. Schöller (2009): "Globalization, Offshoring and Economic Insecurity in Industrialized Countries", United Nations Department of Economic and Social Affairs, DESA Working Paper $8 \%$.

[23] Milberg, W., and D. Winkler (2010a): "Financialisation and the dynamics of offshoring in the USA", Cambridge Journal of Economics, vol. 34, 275-293.

[24] Milberg, W., and D. Winkler (2010b): "Economic insecurity in the new wave of globalization: offshoring and the labor share under varieties of capitalism", International Review of Applied Economics, vol. 24, 285-308.

[25] Orhangazi, O. (2008): "Financialisation and capital accumulation in the non-financial corporate sector: A theoretical and empirical investigation on the US economy: 1973-2003", Cambridge Journal of Economics, 32, 863-886.

[26] Pesaran, M.H. and Shin, Y. (1999): "An Autoregressive Distributed-Lag Modelling Approach to Cointegration Analysis" in Econometrics and Economic Theory in the Twentieth Century: The Ragnar Frisch Centennial Symposium, edited by Strom, S., Cambridge University Press, pp. 371-413.

[27] Pesaran, M.H., Y. Shin, and Smith, R.J. (2001): "Bounds testing approaches to the analysis of level relationships", Journal of Applied Econometrics, vol. 16, pp. 289-326.

[28] Piketty, T. and Saez, E. (2006): "The Evolution of Top Incomes: A Historical and International Perspective", The American Economic Review, vol. 96, 200-205.

[29] Reuters (2010): "Fortune 500 shed record 821,000 jobs in 2009" by Phil Wahba, April 15.

[30] Saez, E. (2010). "Striking it Richer: The Evolution of Top Incomes in the United States", mimeo: http://elsa.berkeley.edu/ saez/saez-UStopincomes-2008.pdf

[31] Shorrocks, A. (2005): "Inequality values and unequal shares", paper presented at the UNUWIDER Jubilee Conference: WIDER thinking ahead: The future of development economics, 17-18 June 2005, Helsinki, Finland.

[32] Stockhammer, E. (2004): "Financialisation and the Slowdown of Accumulation", Cambridge Journal of Economics, vol. 28, 719-741.

[33] Stockhammer, E. (2009): "Determinants of functional income distribution in OECD countries", Macroeconomic Policy Institute IMK Studies 5/2009.

[34] Wolff, E.N. and Zacharias, A. (2006): "Wealth and Income Inequality: Who's at the Top of the Economic Ladder?", The Levy Economics Institute of Bard College, LIMEW Report, December 2006. 